\title{
Література
}

1. Берсенева Т. А. Духовно-нравственные основания традиционного уклада жизни как социально-педагогическая проблема: автореф. дис.. на соискание ученой степени д-ра. пед. наук: 13.00.01 / Тамара Александровна Берсенева. - Курск, 2008. 44 с. 2. Кожедуб Л. Г. Модель навчання читання майбутніх філологів на основі інтерпретації лінгвостилістичних засобів художніх текстів / Л. Г. Кожедуб // Іноземні мови : [наук.-метод. журн.] / засн. Київський лінгвістичний університет і вид-во «Ленвіт»; гол. ред. С. Ю. Ніколаєва. - К. : Вид-во «Ленвіт», - 2009. - № 3. - С. 31-35. 3. Куликова Я. А. Изучение сформированности гуманистических ценностных ориентаций студенческой молодёжи / Я. А. Куликова // Социально-экономические явления и процессы. - 2012. - № 1 (035). - С. 260-263. 4. Мальковский Г. Е. Домашнее чтение на английском языке в неязыковом вузе / Г. Е. Мальковский // Іноземні мови : [наук.метод. журн.] / засн. Київський лінгвістичний університет і вид-во «Ленвіт» ; гол. ред. С. Ю. Ніколаєва. - К. : Вид-во «Ленвіт», - 2005. - № 4. - С. 28-30. 5. Методика навчання іноземних мов і культур: теорія і практика: підручник [для студ. Класичних, педагогічних і лінгвістичних ун-тів] / О. Б. Бігич, Н. Ф. Бориско, Г. Е. Борецька [та ін.] ; за заг. ред. С. Ю. Ніколаєвої. - К. : Ленвіт, 2013. - 590 с. 6. Ніколаєнко О. В. До формування соціокультурних та морально-етичних цінностей у студентів ВНЗ у процесі вивчення іноземної мови / О.В.Ніколаєнко, Т. О. Ушата // Вісник Чернігівського державного педагогічного університету імені Т. Г. Шевченка. - Випуск 62. Серія: педагогічні науки: збірник. - Чернігів : ЧДПУ, 2009. - № 62. - 224 с. [Електронний ресурс]. Режим доступу: http://www.uk.xlibx.com/4istoriya/ 15325-41-visnik -chernigivskogoderzhavnogo-pedagogichnogo-universitetu-vipusk-seriya-pedagogichni-nauki-chernigiv2009-1.php 7. Первова Г. М. Духовно-нравственное воспитание студентов средствами чтения / Г. М. Первова // Социально-экономические явления и процессы, 2014. - № 4 (062). - С. 161-164. 8. Тепла О. М. Формування гуманістичних цінностей у студентів аграрних вищих навчальних закладів у позааудиторній діяльності : автореф. дис. на здобуття наукового ступеня канд. пед. наук: 13.00 .07 / Оксана Миколаївна Тепла. - К. 2008. - 23 c. 9. Henry O. The Last Leaf [Web site].- Access mode : http://www.pages.drexel.edu/ ina22/+270/\$270-texts-last_leaf.html 10. Moses [Web site]. Access mode: http://www.michelangelo-gallery.com/ michelangelo-moses.aspx 11. Satyr / British Dictionary definitions for satyr [Web site].- Access mode :http:/dictionary.reference.com/browse/satyr 12. Specific Teaching Suggestions «The Last Leaf» by O. Henry [Web site]. - Access mode: http://www.balancepublishing. com/ leaf \%20teacher.pdf

УДК $811.161 .2: 373$

Уляна Соловій

\section{ПРОБЛЕМНІ АСПЕКТИ ВИКЛАДАННЯ НАВЧАЛЬНОЇ ДИСЦИПЛІНИ «УКРАЇНСЬКА МОВА (ЗА ПРОФЕСІЙНИМ СПРЯМУВАННЯМ)» У ВИЩИХ МЕДИЧНИХ НАВЧАЛЬНИХ ЗАКЛАДАХ}

Соловій У. В. Проблемні аспекти викладання навчальної дисципліни «Українська мова (за професійним спрямуванням)» у вищих медичних навчальних закладах.

У статті порушено актуальні питання викладання «Української мови (за професійним спрямуванням)» у вищих медичних навчальних закладах як нормативної навчальної дисципліни, аргументується необхідність її вивчення у процесі досягнення високого рівня фахової підготовки та формування комунікативної, професійно 
зорієнтованої компетенції майбутніх медиків.

Ключові слова: комунікативна, професійно орієнтована компетенція; мовна підготовка; нормативність; обов'язковість; професійна комунікація; українська мова (за професійним спрямуванням).

Соловий У. В. Проблемные аспекты преподавания учебной дисциплины «Украинский язык (за профессиональной направленностью)» в высших медицинских учебных заведениях.

В статье затрагиваются актуальные вопросы преподавания «Украинского языка (за профессиональной направленностью)» в высших медицинских учебных заведениях как нормативной учебной дисциплины, аргументируется необходимость его изучения в процессе достижения высокого уровня специальной подготовки и формирования коммуникативной, профессионально ориентированной компетенции будущих медиков.

Ключевые слова: коммуникативная, профессионально ориентированная компетенция; языковая подготовка; нормативность; обязательность; профессиональная коммуникация; украинский язык (за профессиональной направленностью).

Solovij U. V. The problematic aspects of teaching Ukrainian language for professional orientation at higher medical institutions.

The current problems of teaching Ukrainian language for professional orientation at higher medical institutions both as a normative and a compulsory discipline are examined in the article; the necessity of learning it in the process of gaining the high degree of the professional training and forming the communicative, professionally orientated competence of future doctors (pharmacists) is argued.

Key words: communicative, professionally orientated competence, language training, normativity; obligation, professional competence, Ukrainian language for professional orientation.

Оновлення сутності процесу навчання $є$ визначальним для реформування вищої освіти в Україні, іiі актуалізації та відповідності сучасним вимогам суспільства. Виникає об'єктивна потреба сформувати особистість 3 чіткою комунікативною, професійно зорієнтованою компетенцією, яка здатна реалізувати власний творчий потенціал на користь держави. Це зумовлює необхідність оволодіння навчальними дисциплінами гуманітарного циклу у вищих навчальних закладах нефілологічного профілю, зокрема «Українською мовою (за професійним спрямуванням)».

Однак на сучасному етапі трансформації структури навчального процесу у вищих навчальних закладах, зокрема медичних, порушується питання про переведення «Української мови (за професійним спрямуванням)» поряд 3 іншими навчальними дисциплінами гуманітарного циклу в розряд дисциплін за вільним вибором студента [4].

Саме тому у статті є мета аргументувати необхідність та обов'язковість навчальної дисципліни «Українська мова (за професійним спрямуванням)» в освітньопрофесійних програмах та навчальних планах підготовки спеціалістів медичного спрямування.

Важливість «Української мови (за професійним спрямуванням)» у гуманітарному циклі галузевих стандартів вищої освіти напрямку підготовки 1101 «Медицина», а отже, й у робочих навчальних планах вищих навчальних закладів 
нефілологічного профілю репрезентується законом України «Про вищу освіту» від 01.07.2014 № 1556-VII, який «...створює умови для ... поєднання освіти 3 наукою та виробництвом задля підготовки конкурентоспроможного людського капіталу для високотехнологічного та інноваційного розвитку країни, самореалізації особистості, забезпечення потреб суспільства, ринку праці та держави у кваліфікованих фахівцях» $[5]$.

У розділі I «Загальних положень» закону України «Про вищу освіту» від 01.07.2014 № 1556-VII (Стаття 1. Основні терміни та їх визначення) вища освіта вважається «сукупністю систематизованих знань, умінь i практичних навичок, способів мислення, професійних, світоглядних і громадянських якостей, моральноетичних цінностей, інших компетентностей, здобутих у вищому навчальному закладі (науковій установі) у відповідній галузі знань за певною кваліфікацією на рівнях вищої освіти, що за складністю є вищими, ніж рівень повної загальної середньої освіти» [5]. Саме тому розгляд «Української мови (за професійним спрямуванням)» як нормативної дисципліни у робочих планах вищих навчальних закладів визначається насамперед іiі завданнями:

- сформувати мовну компетентність майбутніх фахівців, що передбачає знання та практичне оволодіння нормами літературної професійної мови;

- сформувати індивідуальний термінологічний лексикон майбутнього медика й уміння оперувати фаховою термінологією;

- сформувати стійкі навички усного й писемного мовлення, зорієнтованого на професійну специфіку;

- сформувати вміння та навички оптимальної мовленнєвої поведінки як підгрунтя професійного формування медика;

- сформувати чітку наукову, професійно зорієнтовану компетенцію як невід'ємний складник фахової діяльності майбутнього медика.

Отже, володіння сучасною українською літературною мовою професійної сфери, досягнуте через вивчення дисципліни «Українська мова (за професійним спрямуванням)», позитивно вплине на рівень фахової підготовки та кваліфікації майбутніх медиків.

Щоб репрезентувати належний рівень оперування усним та писемним мовленням, необхідно систематично вдосконалювати професійну комунікативну компетенцію, а також уміння й навички наукової діяльності в медичній галузі.

Професійний аспект мовлення не може функціонувати ізольовано, а перебуває у тісних взаємозв'язках з усіма галузями мовознавства: фонетикою, орфографією, орфоепією, етимологією, лексикологією (зокрема термінознавством), лексикографією, граматикою, стилістикою тощо. Тому, створюючи належні умови задля результативної мовленнєвої, професійно зорієнтованої комунікації, насамперед слід спиратися на мовні знання, навички й уміння, набуті на базі повної середньої освіти, удосконалені й безпосередньо спрямовані на «..вибір оптимальних мовних ресурсів...» [3, с. 162], 3 допомогою яких можна досягнути поставленої мети вирішення певного комунікативного завдання. Цей підхід дозволяє простежити особливості вживання граматичних форм у різних умовах спілкування; виявити функціонально-стилістичне навантаження морфологічних та лексичних одиниць; максимально реалізувати всі типи літературних мовних норм в усному та писемному мовленні: орфоепічні, акцентуаційні, лексичні, граматичні, стилістичні, орфографічні, пунктуаційні.

Сформована таким способом мовна професійна компетентність як «сукупність 
систематизованих знань норм і правил літературної мови, за якими будуються правильні мовні конструкції та повідомлення за фахом» [7, с. 18], відповідно, передбачає створення грамотної, мовленнєво та професійно компетентної особистості, яка, крім уміння об'єктивно передавати чи сприймати певну інформацію у процесі фахового спілкування, знатиме й віртуозно користуватиметься стратегією досягнення поставленої мети під час комунікації (професійної зокрема) як «смислового та ідеально-змістового аспекту соціальної взаємодії» [3, с. 162].

На практичних заняттях 3 «Української мови (за професійним спрямування)» тексти 3 науковою чи науково-популярною формою викладу, лексико-граматичні завдання безпосередньо відповідають умовам реального професійного спілкування медиків; мовний матеріал, що ілюструє відповідні розділи мовознавства, реалізується в практичному аспекті. Акцентування у такий спосіб здійснюється насамперед на комунікативній та пізнавальній функціях мови.

Завдяки ознайомленню 3 особливостями творення та функціонування української медичної термінології на лексичному та граматичному рівнях сучасної української мови; проблемами сучасного термінознавства, пов'язаними зі співіснуванням чи взаємозапереченням термінів-запозичень і термінів, утворених на власне українському мовному грунті; 3 міжгалузевими загальнонауковими термінологічними одиницями, професіоналізмами й навіть професійними жаргонізмами майбутній спеціаліст розширює власне лексичний і термінологічний запас, навчається об'єктивно аналізувати й оцінювати проблемні аспекти медичної терміносистеми сьогодення.

Вивчення особливостей використання медичної лексики та слововживання в українській мові та їх реалізації у діалогах лікаря 3 хворим; ознайомлення 3 професійним комунікативним етикетом; оволодіння мистецтвом аргументації, умінням організовувати та репрезентувати публічний виступ як необхідний засіб комунікації переконання; вдосконалення навичок невербального спілкування створює підгрунтя для формування висококваліфікованого, освіченого комунікативно зорієнтованого медичного працівника.

Засвоєння граматичних конструкцій, що є основою побудови речень у наукових, науково-навчальних чи науково-популярних текстах 3 дисциплін клінічного циклу та циклу дисциплін природничо-наукової підготовки у вищих медичних навчальних закладах, дозволить удосконалити навички написання й редагування наукових текстів 3 урахуванням труднощів узгодження, складних випадків керування, особливостей побудови речень 3 однорідними членами; найхарактерніших стилістичних помилок, що грунтуються на використанні невластивих українській мові синтаксичних конструкцій, граматичних форм тощо.

Ознайомлення 3 основними принципами наукової комунікації як невід'ємного складника фахової діяльності майбутнього медика, формами вербального втілення результатів наукових досліджень (наукового звіту, наукової праці, наукової доповіді, наукового повідомлення про науково-дослідну роботу, монографічного дослідження, наукового відкриття тощо); методами фіксації і збереження наукової інформації (планом, тезами, виписками, цитатами, конспектом); особливостями бібліографічного опису джерел, оформлювання покликань; анотування й реферування наукових текстів дозволить студентам (молодим науковцям, аспірантам) сформувати комунікативну, професійно й науково орієнтовану компетенцію, що визначає перспективи їхньої участі у всеукраїнських наукових і науково-практичних конференціях; удосконалює вміння вести наукову кореспонденцію та публікувати статті чи тези доповідей у фахових національних (періодичних чи електронних) виданнях, матеріалах 
всеукраїнських (з міжнародною участю) форумах.

Робота 3 найновішими різновидами медичної документації (їх укладанням та оформленням) сприяє закріпленню вивченого мовного матеріалу на практичному рівні функціонування літературної професійної мови.

Запропоновані напрямки викладання i засвоєння змістового наповнення дисципліни є актуальними для роботи в аудиторії (практичні заняття), дистанційного навчання, самостійного опрацювання, створення програм відповідних елективних курсів та свідчать на користь нормативності та обов'язковості навчальної дисципліни «Українська мова (за професійним спрямуванням)» у вищих медичних навчальних закладах. Вони повною мірою реалізують мету курсу: опанувати літературну професійну мову на рівні фахового спілкування, розширити лексичний i термінологічний запас для подальшого його використання у процесі здобування вищої медичної освіти.

\section{Література}

1. Мацюк 3. Українська мова професійного спілкування : [навч. посібн]. / Зоряна Мацюк, Ніна Станкевич. - К. : Каравела, 2010. - 352 с. 2. Литвиненко Н. П., Українська медична термінологія у фаховій мові лікаря: [навч. посіб.]/ Н. П. Литвиненко, Н. В. Місник. - К. : Книга-плюс, 2008. - 176 с. 3. Лінгвістичний аналіз тексту: словник термінів / [Голянич М. І., Іванишин Н. Я., Ріжко Р. Л., Стефурак Р. І.] ; за редакцією М. І. Голянич. - Івано-Франківськ : Сімик, 2012. - 392 с. 4. Наказ Міністерства освіти і науки України № 1392 від 25.11.2014 «Про визначенням таким, що втратив чинність, наказ Міністерства освіти і науки України від 09.07.2009 № 642» [Електронний ресурс]. - Режим доступу: http://www.mon. gov.ua/ua/ about-ministry/normative/32360. 5. Про вищу освіту: Закон України від 1 липня 2014 року № 1556-VII // Відомості Верховної Ради України. - 2014. - № 37-38. 6. Фахова мова медика: українська мова за професійним спрямуванням : [навч. посіб.] / Н. П. Литвиненко, Н. В. Місник. - К. : Книга-плюс, 2012. - 333 с. 7. Шевчук С. В. Українська мова за професійним спрямуванням : [підручник].С. В. Шевчук, І. В. Клименко. - [3-тє вид., виправ. і доповнен.] - К. : Алерта, 2013. $696 \mathrm{c}$.

УДК 378.147

Наталія Соловйова, Ніна Ігнатюк

\section{РОЗВИТОК УНІВЕРСАЛЬНИХ УМІНЬ У ПРОЦЕСІ ЧИТАННЯ ІНШОМОВНИХ ТЕКСТІВ}

Соловйова Н. Д., Ігнатюк Н. А. Розвиток універсальних умінь у процесі читання іншомовних текстів.

У статті пропонуються можливі шляхи для підготовки випускників вишів задля подальшої самоосвіти. Розглянуто необхідність формування універсальних умінь студентів на основі використання технології розвитку критичного мислення, наведено приклади застосування графічних організаторів у процесі читання текстів іноземною мовою.

Ключові слова: універсальні вміння, критичне мислення, саморозвиток особистості, графічні організатори, читання.

Соловьева Н. Д. Игнатюк Н. А. Развитие универсальных умений в процессе чтения иноязычных текстов.

В статье предлагаются возможные пути подготовки выпускников вузов к 